\title{
Spectroscopic Approach for Characterization of Archaeological Potsherds Excavated from Some Neolithic Sites from Sudan
}

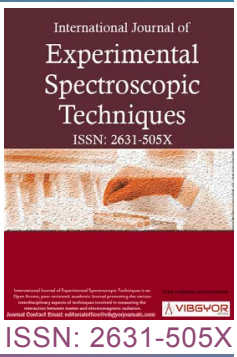

Fatima Elbashir Siddig1', Abdalla Ahmed Elbashir", Verena Lepper ${ }^{2}$ and Ahmed Hussein ${ }^{3}$

${ }^{1}$ Faculty of Science, Department of Chemistry, University of Khartoum, Khartoum, Sudan

${ }^{2}$ Ägyptisches Museum und Papyrussammlung, Staatliche Museen zu Berlin - Preußischer Kulturbesitz, Germany

${ }^{3}$ Faculty of Art, Department of Archaeology, University of Khartoum, Khartoum, Sudan

\begin{abstract}
In this paper multi-spectroscopic techniques for characterization of ancient potsherds excavated from different Neolithic sites (Esh-shaheinab, Kadero and Jebel-Um-Marahi), Sudan were reported. The experimental data inform us to the both elemental and mineralogical composition of the potsherds. Mineralogical composition of ancient pottery has been studied by both FTIR and XRD approaches. Further, studies by Thermogravimetric analysis (TGA) to indicate the firing temperature from typical thermal reaction in potsherds samples. Scanning Electron Microscopy (SEM) coupled with an Energy Dispersive Spectrometer (EDS) was used to study the internal morphology and chemical composition of the pottery. EDS was performed to figure out the elemental composition and the resultants were carried out statistically utilizing the ratio of $\mathrm{SiO}_{2}$ to $\mathrm{Al}_{2} \mathrm{O}_{3}$ due to their non-volatile character. However, XRD results Revealed the mineralogical composition of the potsherds the quartz is predominant all over the samples then microcline, illite, muscovite, albite, magnesium aluminum silicon oxides and rutile in different compositions and various firing temperatures of pottery samples were found to be in the 800 $1100^{\circ} \mathrm{C}$.
\end{abstract}

Keywords

FTIR, SEM-EDS, XRD, ED-XRF, TGA

\section{Introduction}

Multi-analytical techniques approach is being well recognized in the area of archaeological research to have complete enlightenment [1]. The general purpose is quantitative measurements in solving problems related to assumption the origin of archaeological and arts materials and methodologies, the identification of these materials in re- spect of human cultural history, and to assistance in preservation and conservation of the artifacts to the future, also they give significant information regarding to the materials and production procedure of archaeological artifacts [2].

Archaeological pottery provides knowledge earned from over several decades to the recent research. Investigation of archaeological pottery has

*Corresponding author: Abdalla Ahmed Elbashir, Faculty of Science, Department of Chemistry, University of Khartoum, Khartoum, 11115, Sudan

Accepted: September 10, 2018; Published: September 12, 2018

Copyright: () 2018 Siddig FE, et al. This is an open-access article distributed under the terms of the Creative Commons Attribution License, which permits unrestricted use, distribution, and reproduction in any medium, provided the original author and source are credited.

Siddig et al. Int J Exp Spectroscopic Tech 2018, 3:017

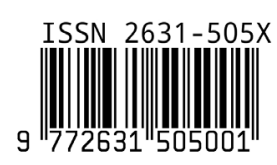


Table 1: Description of potsherds samples.

\begin{tabular}{|c|c|c|c|c|c|}
\hline Samples code & \begin{tabular}{|l|} 
Decorative \\
classification
\end{tabular} & $\begin{array}{l}\text { Interior } \\
\text { colour }\end{array}$ & $\begin{array}{l}\text { Exterior } \\
\text { colour }\end{array}$ & Sites locations & Period \\
\hline \multirow{2}{*}{ UMR-01 } & \multirow{2}{*}{$\begin{array}{l}\text { Decoration arch } \\
\text { shaped line }\end{array}$} & \multirow{2}{*}{ Brown } & \multirow{2}{*}{ Brown } & N 155863 & $(5000-3000 \mathrm{BC})$ \\
\hline & & & & E 3232921 & Neolithic \\
\hline \multirow{2}{*}{ UMR-02 } & \multirow{2}{*}{ Small dotted line } & \multirow{2}{*}{ Dark Brown } & \multirow{2}{*}{ Dark Brown } & & $(5000-3000 \mathrm{BC})$ \\
\hline & & & & & Neolithic \\
\hline \multirow{2}{*}{ UMR-03 } & \multirow{2}{*}{ Undecorated polished } & \multirow{2}{*}{ Red } & \multirow{2}{*}{ Red } & & $(5000-3000 \mathrm{BC})$ \\
\hline & & & & & Neolithic \\
\hline \multirow{2}{*}{ SH-01 } & \multirow{2}{*}{$\begin{array}{l}\text { Dotted line rocker } \\
\text { zigzag }\end{array}$} & \multirow{2}{*}{ Dark grey } & \multirow{2}{*}{ Grey } & N 163306 & $(5000-3000 \mathrm{BC})$ \\
\hline & & & & E 03232525 & Neolithic \\
\hline \multirow{4}{*}{$\mathrm{SH}-02$} & \multirow{4}{*}{ Dotted line } & \multirow{4}{*}{ Black } & \multirow{4}{*}{ Black } & & $(5000-3000 \mathrm{BC})$ \\
\hline & & & & & Neolithic \\
\hline & & & & & $(5000-3000 \mathrm{BC})$ \\
\hline & & & & & Neolithic \\
\hline \multirow{2}{*}{ KDR } & \multirow{2}{*}{$\begin{array}{l}\text { Decoration with } \\
\text { straight lines }\end{array}$} & \multirow{2}{*}{ Red } & \multirow{2}{*}{ Dark red } & N 1554288 & $(5000-3000 \mathrm{BC})$ \\
\hline & & & & E 3255307 & Neolithic \\
\hline
\end{tabular}

evolved into greater extent significant over the previous century, great information about the daily life and culture were given to the archaeologist, minerals investigation of pottery firmly clarify the sort of clay, firing temperature, kiln atmospheric condition implemented by the potter, so, it is essential to assess mineral composition to answer technological issues of pottery manufacturing [3].

Neolithic in Sudan such as Esh Shaheinab and Geili, and domesticates, principally cattle, were overriding at sites such as Kadero c. 5000e4000 BP, where wild plants were also intensively exploited [4]. Jebel-umm marahi, lies on the west bank of the river Nile, north Khartoum, it's a small flat topped sandstone hill in front of the river north of Sheikh El-Tayib village and north of Shaheinab, the ancient site, principally on the summit of the hill, was first discovered by O.G,S Crawford in 1951 [5], Kadero, is situated north of Khartoum [6]. Further information about our samples and their sites details in Table 1.

Characterization of pottery is carried out frequently by Fourier Transform Infrared (FT-IR) spectroscopy analysis and this technique is usefulness in recognize a variety of materials, structure, bonding and chemical properties of clay mineral [7-10]. Moreover, X-ray diffraction technique (XRD) is most common utilized for quantitative characterization of mineralogical composition, its appropri- ate method for repetitive quantitative investigation associated to any other only technique, like Fourier transform infrared spectroscopy (FTIR) and, chemical analysis and electron microscopy [11]. Moreover, the measurable investigation of convinced minerals and specifically of clay minerals residues as a main challenge as a result of the several chemical compositions, chosen orientation, structural disorder and countless structural variety of clay minerals [12].

SEM-EDS was performed for the investigation of major and minor elements of the fresh-fractured surface of pottery samples. Major and minor elements characterization have been utilized to get the interpretation on the origin place of archaeological pottery. Specifically, it may lead to recognize the source of the clay utilized to pottery production. SEM-EDS techniques are rapid element analysis technique small amount of sample is needed [13]. ED-XRF is accomplished too as co-dependent analysis for elemental analysis. XRF spectrometry is a rapid analysis that can be utilized to all material phase solids, powders of liquids and gases too. Furthermore, it is appropriate over wide range of concentrations (from $1 \mathrm{ppm}$ to $100 \%$ ), getting elemental range within Sodium and Uranium [14]. Determination of the sort of clay minerals (Calcareous/Non-Calcareous and even if the pottery is high or low refractory) and calculation of firing atmo- 
sphere assumed by artisan at the time of production was carried out by chemical investigation on the samples [15].

Thermogravimetric analysis is regularly utilized to explore investigated pottery samples, degradation temperatures, amount of absorbed moisture and the proportion of organic and inorganic composition in the archaeological pottery samples; it recognizes one to manage the procedure of firing and show the variation as results of thermal method simultaneously [16].

Statistical approach is usually utilized to determine grouping arrangements of provenance study of the archaeological samples in description of concept of chemical components $[17,18]$.

In this work, seven potsherd samples from Esh-shaheinab, Kadaro and Jebel-Um-Marahi, Neolithic archaeological sites in Sudan, were investigated in order to evaluate consistency between their compositions. For compositional and firing temperature investigation with multi-analytical approach was adopted.

\section{Material and Methods}

\section{Samples and sites details}

For this study, seven selected samples of potsherd were characterized. Three samples from Esh-Shaheinab named as (SH-01, SH-02 and SH-03), one belongs to Kadero (KDR-01) and three belong to Jebel-Um-Marahi named as (UMR-01, UMR-02 and UMR-03) are shown in Figure 1. The photograph and detailed descriptions of the samples are given in Table 1.

\section{Fourier transform infrared spectroscopy (FT-IR)}

The spectra of FT-IR were obtained using FT-IR 8400 S Shimadzu (Japan) Fourier Transform spectrophotometer with a pyroelectric detector operating in the mid Infrared region $\left(400-4000 \mathrm{~cm}^{-1}\right)$ with a typical resolution of $4.0 \mathrm{~cm}^{-1}$. Small quantities of each sample were prepared by grinding with dried $\mathrm{KBr}$ powder and pressing into discs. The fitting of peaks and smoothing were done by IR-solution software in the instrument over the working window $4000-400 \mathrm{~cm}^{-1}$.

\section{Scanning electron microscopy with energy dis- persive spectrometer (SEM-EDS)}

The microphotograph investigations were utilized on an EVO ${ }^{\circledR}$ LS 10 scanning electron microscope at $20 \mathrm{KV}$ an accelerating voltage and 1-3 nA a beam current. The sample coated with thin layer of palladium/gold. The extreme magnification in the technique is 1000.0000 times. The elemental analysis was done using the Oxford INCA EDX energy dispersive spectrometer, for the characterization of the X-ray emitted by the sample to examine the elements composition currently identified by SEM.

\section{Energy dispersive $\mathrm{X}$-ray fluorescence spectrom- eter (ED-XRF)}

The chemical components of the pottery were

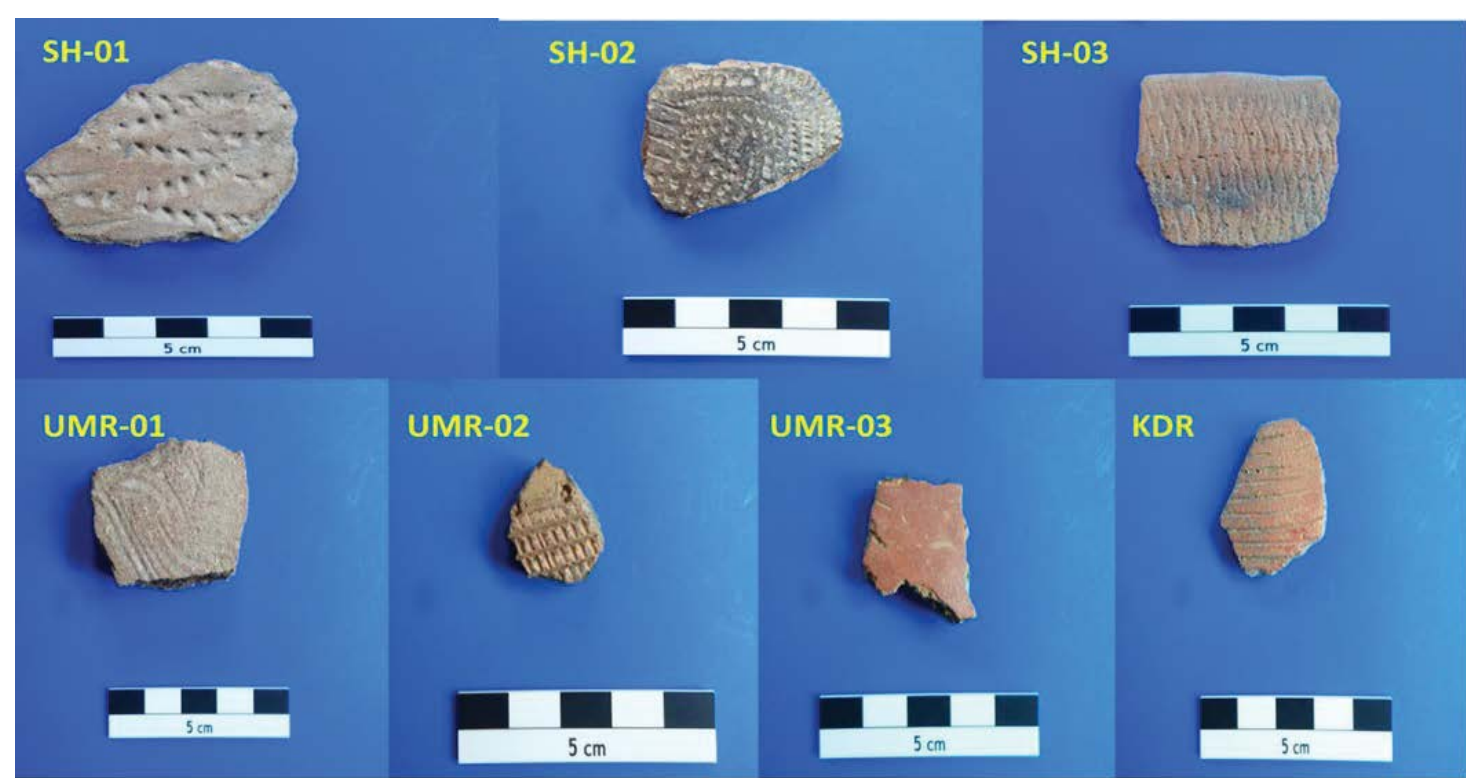

Figure 1: Neolithic pottery samples from Esh-shaheinab (SH-01, SH-02, and SH-03), Kadaro (KDR) and Jebel-Um-Marahi (UMR-01, UMR-02 and UMR-03) archaeological sites. 


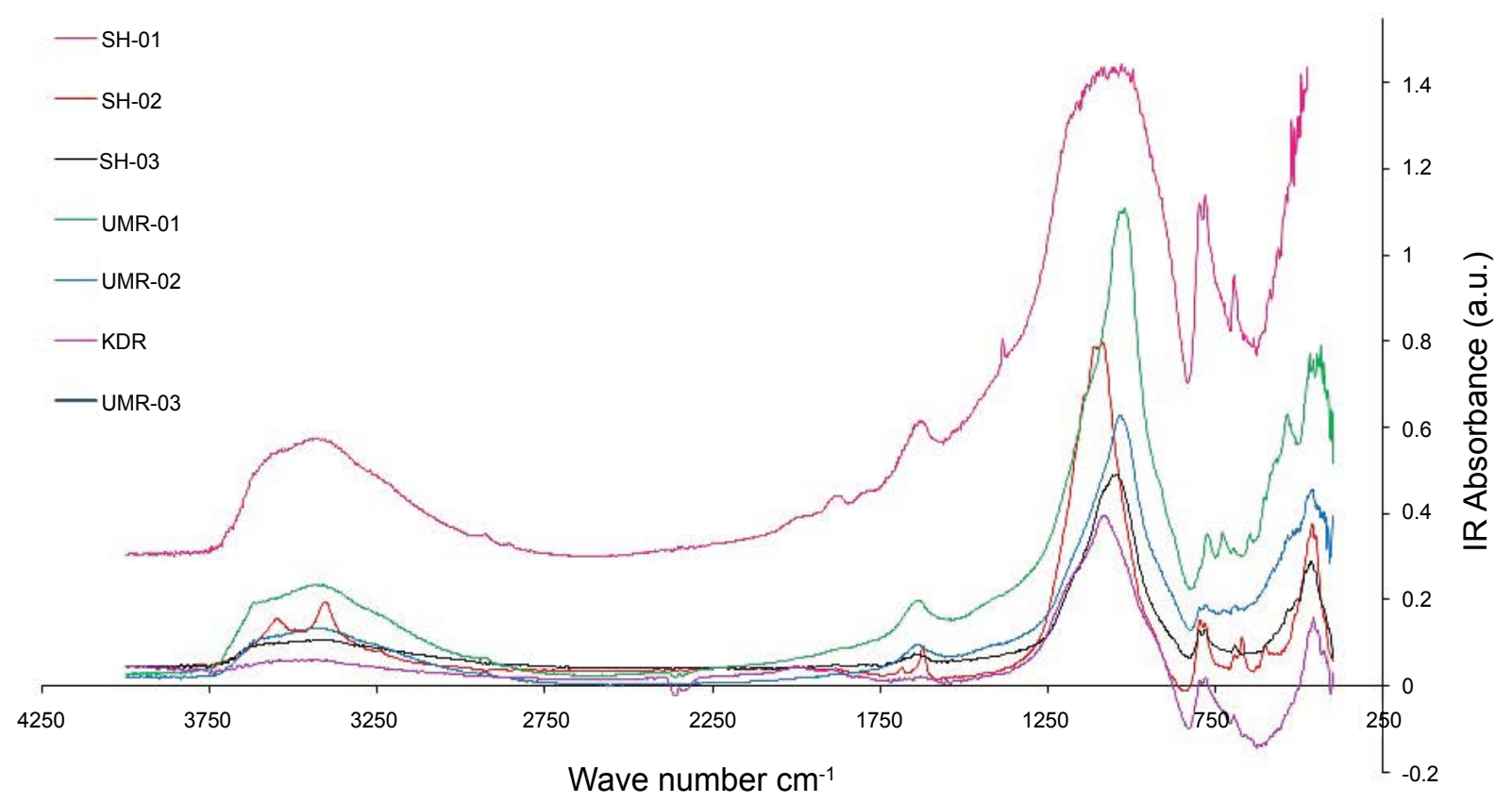

Figure 2: FT-IR spectra of UMR-01, UMR-02, UMR-03, SH-01, SH-02, SH-03, KDR, potsherds samples.

characterized by X-ray fluorescence spectrometer the X-Supreme 8000 (Oxford). The spectrometer coupled with X-ray tube, Si detector with a high-energy resolution. Small quantity of samples was finely powdered by agate mortar. The determination was performed on homogenized powder samples. The software is X-Supreme Software Package.

\section{Thermogravimetric analysis (TGA)}

Thermogravimetric analyses (TGA) were performed with PT1000 Thermogravimetric LINSEIS with thermal advantage software. The experiment was performed by heating the samples up to 950 ${ }^{\circ} \mathrm{C}$ with heating rate of $10{ }^{\circ} \mathrm{C} \mathrm{min}-1$ under high purity atmosphere.

\section{X-ray diffraction analysis (XRD)}

X-ray diffraction analysis for mineralogical composition of potsherds samples, was performed by EXPERT-PRO diffractometer system, the Goniometer: PW3050/60 (Theta/theta); using XPERT data collector, operating with Cu K $\alpha(\lambda=1.54060 \AA)$. The diffraction patterns were recognized at $2 \theta$ angle, in the range between $3-70^{\circ}$ with step size $\left[{ }^{\circ} 2 \theta\right]=$ 0.0200 at a scan step time $0.5 \mathrm{~s}$. The measuring temperature $25^{\circ} \mathrm{C}$, the generator sitting $40 \mathrm{~mA}$, $50 \mathrm{KV}$. The X'Pert HighScore software was carried out for diffraction data interpretation. the mineral structural models from the primary reference Smith Zolensky, Dep Geol Science, Penn State Univ, University Park, PA, USA, ICCD Grant-in-Aid (1979).
Unit cell Meager, E, Can Minerals, 17,77, (1979).

\section{Results and Discussion}

\section{Fourier transform infrared (FT-IR) spectral analysis}

FT-IR spectral absorption bands and its vibrational assignments are utilized to recognize enough characterize of the clay/non-clay mineral composition of the particular potsherd samples Figure 2. FT-IR has been performed to identification of the mineralogical composition and its vibrational sitting apart by comparing the noticed frequencies with available literature. The spectra were reported meanwhile the absorption bands and their vibrational assignments are performed in Table 2. The major bands around $1035 \mathrm{~cm}^{-1}$ directs the obliteration of octahedral sheet enlightening that the samples were fired in the range $\left(700-800^{\circ} \mathrm{C}\right)$ [14], the existence of albeit $470 \mathrm{~cm}^{-1}$ reveal feldspar a group of minerals in the pottery samples and quartz (775 $\mathrm{cm}^{-1}$ ) were performed from the IR absorption spectra $[19,20]$.

The observed absorption bands around 3430 and $1637 \mathrm{~cm}^{-1}$ were distinguishing to adsorbed water molecule the $\mathrm{OH}$ stretching and $\mathrm{H}-\mathrm{O}-\mathrm{H}$ bending respectively that is noticed in majority of the natural silicates [14]. The wave number at around 3620 $\mathrm{cm}^{-1}$ has been assign to the inner hydroxyls (UMR01) and (UMR-03) samples [20]. Through firing, the clay minerals lattice structures regularly disappear- 
Table 2: Observed FT-IR absorption frequencies $\left(\mathrm{cm}^{-1}\right)$ and relative intensities of ancient archaeological pottery fragments.

\begin{tabular}{|c|c|c|c|c|c|c|c|}
\hline FT-IR ab & sorption I & Jands in $\mathrm{u}$ & lave numb & $\mathrm{rs}\left(\mathrm{cm}^{-1}\right) \mathrm{w}$ & h relative & intensities & Tentative vibrational assignments \\
\hline SH-01 & SH-02 & SH-03 & KDR-01 & UMR-01 & UMR-02 & UMR-03 & \\
\hline & & & & 3620 VW & & 3618 VW & OH Stretching, Crystalline hydroxyl \\
\hline $3446 \mathrm{M}$ & $3450 \mathrm{M}$ & $3433 \mathrm{~S}$ & 3415 VS & $3436 \mathrm{M}$ & $3411 \mathrm{M}$ & 3402 W & $\mathrm{O}-\mathrm{H}$ str. of adsorbed water \\
\hline $1645 \mathrm{~W}$ & $1641 \mathrm{~W}$ & $1631 \mathrm{~W}$ & $1629 \mathrm{VW}$ & $1633 \mathrm{M}$ & $1647 \mathrm{~W}$ & $1627 \mathrm{VW}$ & Bending of water \\
\hline & & & $1465 \mathrm{VW}$ & & & & $\mathrm{H}-\mathrm{O}-\mathrm{H}$ stretching of adsorbed water \\
\hline 1041 VS & 1041 VS & 1081 VS & 1080 VS & 1018 VS & 1033 VS & 1035 VS & Si-O Str. of clay minerals \\
\hline $786 \mathrm{M}$ & $788 \mathrm{M}$ & $779 \mathrm{~W}$ & $777 \mathrm{~W}$ & $775 \mathrm{~W}$ & $777 \mathrm{VW}$ & 781 VW & Si-O str. of clay minerals \\
\hline & & & 797 & & $796 \mathrm{VW}$ & & Si-O of quartz \\
\hline & & & & $727 \mathrm{~W}$ & $727 \mathrm{VW}$ & & C-O str. Calcite \\
\hline $686 \mathrm{VW}$ & $688 \mathrm{VW}$ & & $694 \mathrm{VW}$ & $694 \mathrm{VW}$ & $692 \mathrm{VW}$ & $696 \mathrm{VW}$ & Si-O bending of quartz \\
\hline $642 \mathrm{VW}$ & & & & $646 \mathrm{VW}$ & & & Al-O-Si str. of feldspar \\
\hline & & & & $538 \mathrm{~W}$ & $518 \mathrm{VW}$ & $538 \mathrm{VW}$ & Fe-O bend of Hematite \\
\hline $470 \mathrm{~s}$ & $451 \mathrm{M}$ & $451 \mathrm{M}$ & $457 \mathrm{~W}$ & $468 \mathrm{VW}$ & $460 \mathrm{~W}$ & $468 \mathrm{~W}$ & Si-O-Si bending of silicates \\
\hline
\end{tabular}

VS: Very strong; S: Strong; M: Medium; W: Week; VW: Very week.

Table 3: Verification stages and firing temperature ranges of represented pottery sherds.

\begin{tabular}{|l|l|l|l|l|}
\hline Sample code & CaO $\%$ & Clay type & Verification stage & Estimating Firing temperature ${ }^{\circ} \mathbf{C}$ \\
\hline UMR-01 & 1.89 & NC & IV & $750-800$ \\
\hline UMR-02 & 1.89 & NC & NV & $<750$ \\
\hline UMR-03 & 2.3 & NC & NV & $750-800$ \\
\hline KDR & 1.45 & NC & IV & $750-800$ \\
\hline SH-01 & 5.04 & NC & IV & $750-800$ \\
\hline SH-02 & 1.54 & NC & NV & $750-800$ \\
\hline SH-03 & 1.19 & NC & NV & $<750$ \\
\hline
\end{tabular}

NC: Non-calcareous; IV: Initial verification; NV: No verification.

ing when the temperature is increased continuously. All samples investigated reveal the absent of band at $915 \mathrm{~cm}^{-1}$ indicating that firing temperature was above $500^{\circ} \mathrm{C}$, as approved by Ravisankar, et al. 2011 [19].

The samples (SH-01, SH-02, UMR-01 and UMR03) have (Si-O) band around $1030 \mathrm{~cm}^{-1}$ suggested that the firing temperature was in range of $700-800$ ${ }^{\circ} \mathrm{C}$ as shown in Table 2 . These results were in agreement with the results obtained by Farmer [21] and De Benedetto, et al. [22]. Strong absorption band in the region 3402-3446 $\mathrm{cm}^{-1}$ and weak bands in the region about $1629-1639 \mathrm{~cm}^{-1}$ in all the samples are resulted from adsorbed water $[16,23]$.

It has been reported that the presence of peak at $540 \mathrm{~cm}^{-1}$ indicate that the sample contain hematite and that was formed during the time of production [24]. Our samples UMR-01, UMR-02 and UMR-03, are characterized by peak at $538 \mathrm{~cm}^{-1}$ that indicate the existence of iron oxides and also that the firing temperature at more than $650^{\circ} \mathrm{C}$. The hematite in three potsherd samples UMR-01, UMR-02 and UMR-03 were fired in open air or oxidizing atmosphere [19].

\section{Scanning electron microscope coupled with en-} ergy dispersive spectroscopy (SEM-EDS) analysis

Scanning electron microscopy has been carried out for identification of the micro-morphology of archaeological pottery and their degree of vitrification for long time. Degree of vitrification commit to which the singular mineral substances in the clay have started to melting and connection to each another [25]. Calcium is one of the most important elements which characterize the physical and chemical properties of soil, two fundamental kinds of clay are calcareous ( $\mathrm{CaO}>6 \%$ ) and as non-calcareous $(\mathrm{CaO}<6 \%)$ as shown in Table 3 [16].

Utilizing SEM to investigate archaeological pottery and determine ancient ceramic method. That the existence of $\mathrm{Ca}$ as fine grained and constantly distributed spread calcite in clay remarkably result the establishment of vitrification, when calcium existing in the sample, for instance $\mathrm{CaCO}_{3}$ dissoci- 


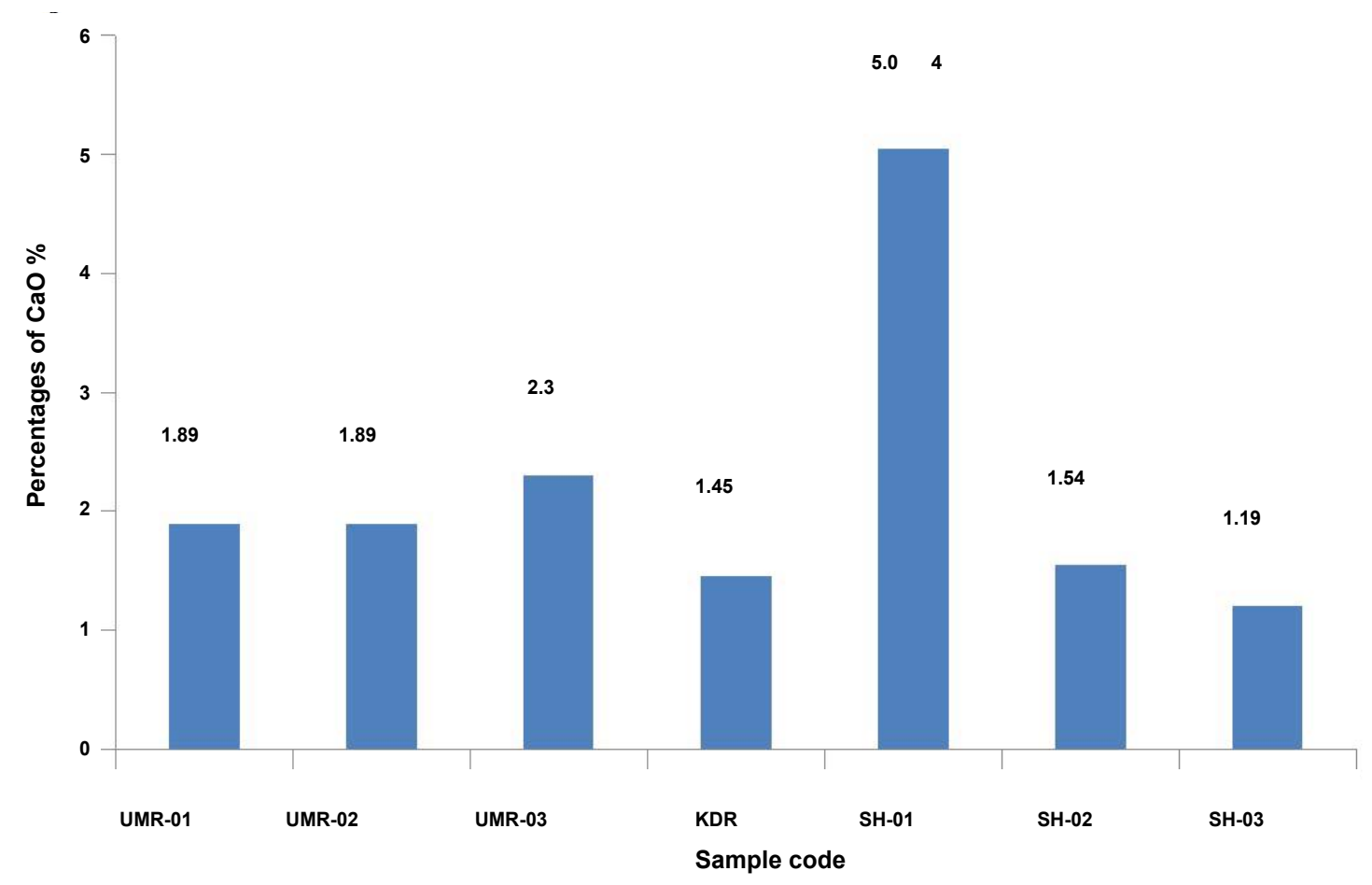

Figure 3: Vitrification of $\mathrm{CaO} \%$ in the potsherds sample.
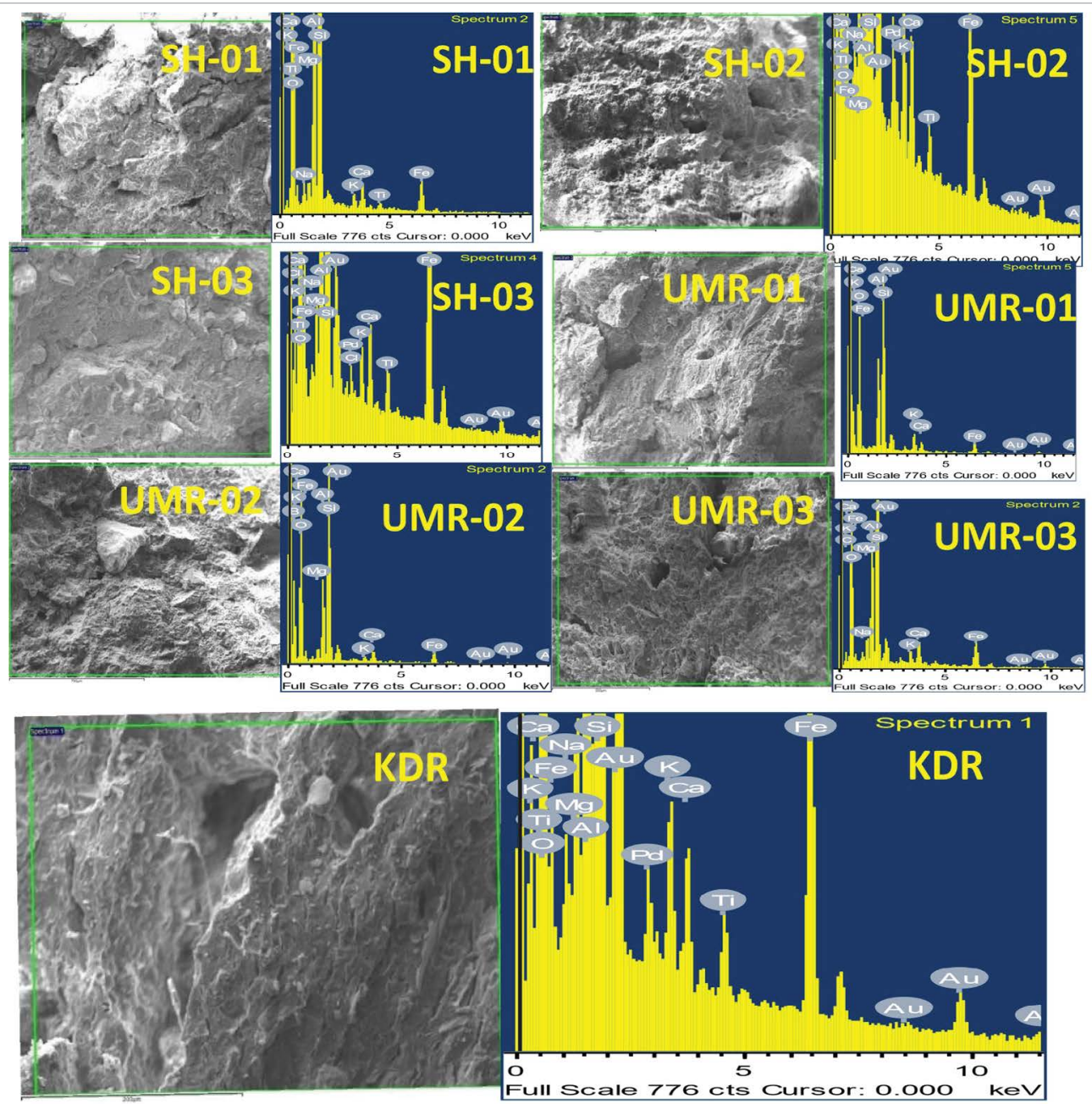

Figure 4: SEM micrographs and EDS spectra of pottery shards: (1) SH-01, (2) SH-02, (3) SH-03, (4) UMR-01, (5) UMR-02, (6) UMR-03, (7) KDR, potsherds samples. 
ates into $\mathrm{CaO}$ and vitrification sets in about $850^{\circ} \mathrm{C}$. Moreover, the non-calcareous clay fired temperature less than $800{ }^{\circ} \mathrm{C}$ will provide no vitrification [16]. Our potsherds also provide no vitrification in received state is confirmation of firing temperature below $800{ }^{\circ} \mathrm{C}$ during production by artisans. From EDS results, it is clear that all the samples investigated were non-calcareous (concentration of $\mathrm{CaO}$ less than 6\%) as shown in Figure 3 [26].

The image of SEM micrographs and EDS spectra of representative potsherd samples are shown in
Figure 4. From EDS investigation, the pottery samples principally have the concentration of Silica $\left(\mathrm{SiO}_{2}\right)$, Alumina $\left(\mathrm{Al}_{2} \mathrm{O}_{3}\right)$ and Fluxes $\left(\mathrm{K}_{2} \mathrm{O}, \mathrm{Fe}_{2} \mathrm{O}_{3}, \mathrm{CaO}\right.$, $\mathrm{MgO}$ and $\mathrm{TiO}_{2}$ ) as the main compositions were recognized in all the samples except MgO in KDR and $\mathrm{TiO}_{2}$ in both samples UMR-01 and UMR-02, All the potsherds are containing the fluxes greater than $9 \%$ and are categorized as low refractory clay [3]. In the present study UMR-02 and $\mathrm{SH}-03$ archaeological pottery investigation reveals that the non-calcareous with low refractory and the lack of smooth

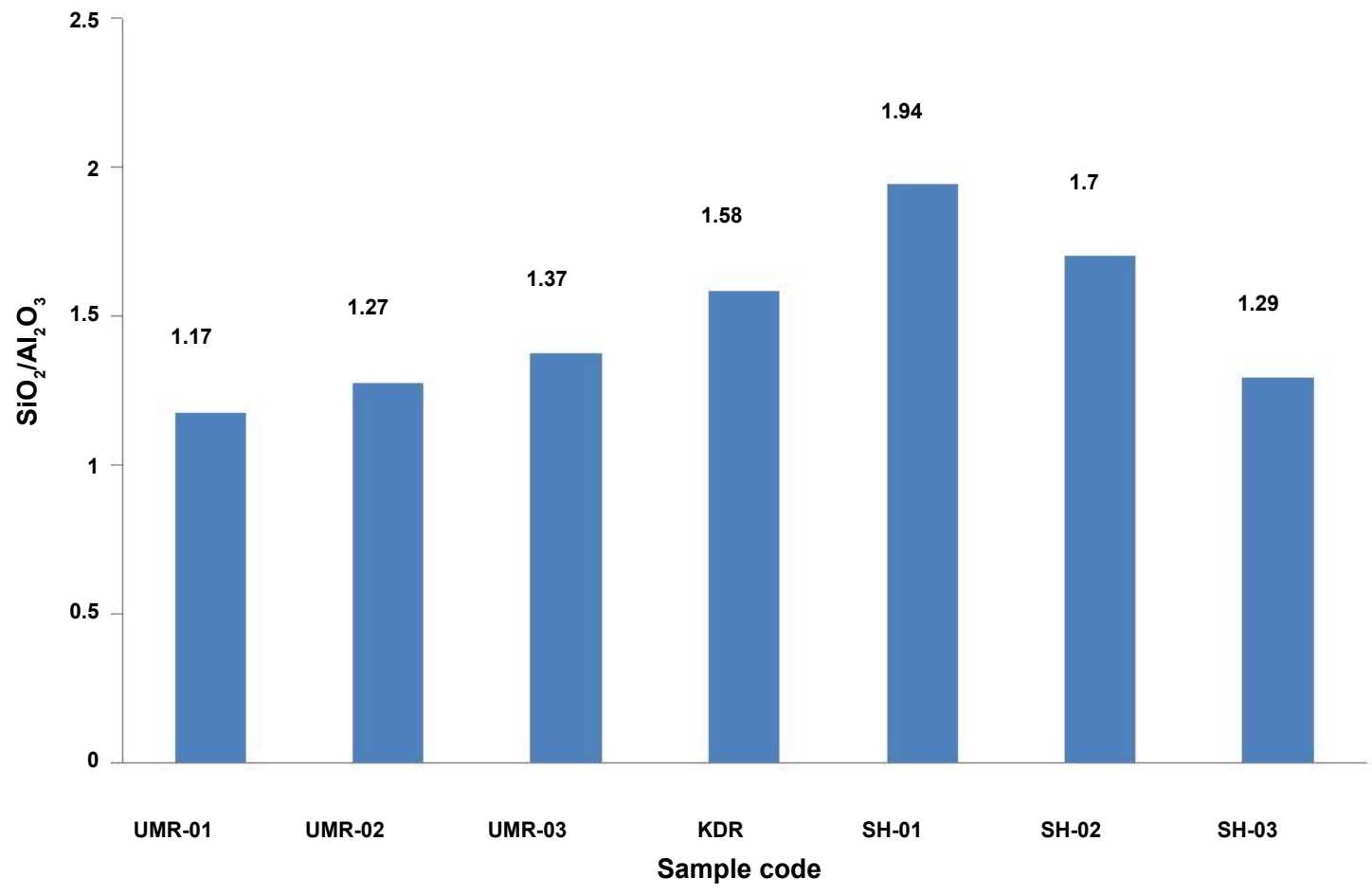

Figure 5: $\mathrm{SiO}_{2} / \mathrm{Al}_{2} \mathrm{O}_{3}$ of potsherds samples.

Table 4: Chemical compositions (XRF) of pottery sherds.

\begin{tabular}{|l|l|l|l|l|l|l|l|}
\hline Oxides & \multicolumn{9}{l}{ Concentrations of elemental oxides (\%) } \\
& UMR-01 & UMR-02 & UMR-03 & KDR & SH-01 & SH-02 & SH-03 \\
\hline $\mathrm{SiO}_{2}$ & 56.855 & 57.388 & 54.441 & 58.671 & 64.952 & 62.125 & 53.743 \\
\hline $\mathrm{Al}_{2} \mathrm{O}_{3}$ & 20.470 & 16.207 & 18.632 & 16.530 & 15.221 & 14.506 & 17.62 \\
\hline $\mathrm{Fe}_{2} \mathrm{O}_{3}$ & 11.406 & 11.433 & 15.079 & 13.136 & 9.803 & 11.083 & 14.154 \\
\hline $\mathrm{K}_{2} \mathrm{O}$ & 5.179 & 1.749 & 1.013 & 2.711 & 2.528 & 1.749 & 2.196 \\
\hline $\mathrm{CaO}$ & 3.271 & 3.867 & 3.296 & 2.589 & 2.902 & 3.014 & 4.210 \\
\hline $\mathrm{TiO}_{2}$ & 1.309 & 2.241 & 1.629 & 1.919 & 2.096 & 3.014 & 2.017 \\
\hline $\mathrm{Mn}_{2} \mathrm{O}_{3}$ & 0.077 & 0.234 & 0.153 & 0.230 & 0.235 & 0.218 & 0.206 \\
\hline $\mathrm{MgO}^{\mathrm{SO}}$ & 0.765 & 2.472 & 2.543 & 1.848 & 1.112 & 1.714 & 1.819 \\
\hline $\mathrm{Na}_{2} \mathrm{O}$ & 0.329 & 1.755 & 1.147 & 0.739 & 0.717 & 1.001 & 2.014 \\
\hline $\mathrm{P}_{2} \mathrm{O}_{5}$ & 0.068 & 0.105 & 0.180 & 0.047 & 0.600 & 0.204 & 0.398 \\
\hline $\mathrm{Cl}$ & 0.156 & 1.985 & 1.439 & 0.0794 & 0.769 & 0.502 & 0.996 \\
\hline
\end{tabular}


surface area that are guide of no-vitrification (NV) in the received state, the firing temperature is less than $750{ }^{\circ} \mathrm{C}$, The rest samples are partially smooth surfaced, non-calcareous and low refractory guides the started firing temperature is around $750-800{ }^{\circ} \mathrm{C}$ [14] and the results is listed in Table 3.

\section{X-Ray florescence analysis (XRF) and chemom- etric analysis}

The chemical component of clay pottery is powerfuly related to the origin of clay and production procedure of pottery $[27,28]$. The concentration ratios of $\mathrm{SiO}_{2} / \mathrm{Al}_{2} \mathrm{O}_{3}$ were shown in Figure 5 and the data for all seven samples were given in Table 4 are classified into three groups (UMR-01, UMR-03 and SH-03), the other group is (UMR-02 and KDR) and (SH-01 and SH-02), these results are suggested that they are of slightly consistent in their origin [25] Figure 6.

\section{Thermogravimetric analysis (TGA)}

The results obtained from TGA investigation of potsherds are presented in Figure 7. which shown the relative mass loss (\%) that took place at typical temperature ranges. The weight loss of the pottery samples Table 5, can be determined as following, the first step ranging from 25 to $100^{\circ} \mathrm{C}$ as a result of dehydration, the second step in the range between $400-500{ }^{\circ} \mathrm{C}$ the weight loss is due to decomposition of hydroxyls, finally the loss of weight in the range $700-800{ }^{\circ} \mathrm{C}$ is because of the decomposition of carbonates, principally calcite [29].

The current analysis potsherds samples of $\mathrm{SH}$ 01, SH-02, UMR-02 and UMR-03 have quit similar thermal behavior, in the range between $25-200{ }^{\circ} \mathrm{C}$ as a result of dehydration of water, may due to the deletion of hygroscopic water from illite, on the other hand, KDR and UMR-01 samples in the range $350-450{ }^{\circ} \mathrm{C}$ are recognized to the oxidation of organic material, principal to a weight loss [17].

Pottery sample $\mathrm{SH}-03$ has dissimilar thermal behavior. As is shown Figure 7, tiny mass loss was ob-

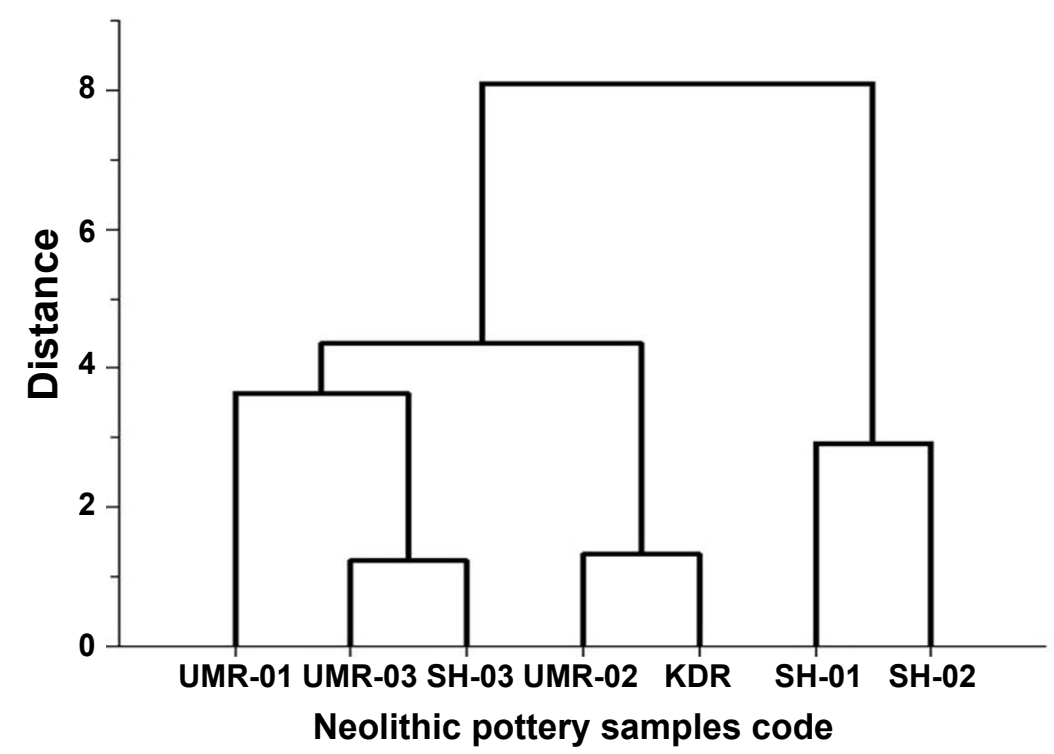

Figure 6: Dendrogram XRF data of $\mathrm{SiO}_{2} / \mathrm{Al}_{2} \mathrm{O}_{3}$ of the potsherds samples.

Table 5: Mineral phases obtained by XRD technique.

\begin{tabular}{|l|l|l|l|l|l|l|l|}
\hline Minerals & UMR-01 & UMR-02 & UMR-03 & SH-01 & SH-02 & SH-03 & KDR \\
\hline Quartz & + & + & + & + & + & + & + \\
\hline Albite & - & + & + & - & - & + & - \\
\hline Microcline & + & - & - & - & - & + & - \\
\hline Mica/Illite & + & - & - & - & - & - & - \\
\hline Muscovite & - & - & - & - & - & + & - \\
\hline Illite & - & + & + & - & - & - \\
\hline Magnesium Aluminum Silicon Oxides & - & - & - & - & - & - & + \\
\hline Rutile & - & - & - & + & + & - & - \\
\hline
\end{tabular}

(+: Present; -: absent). 


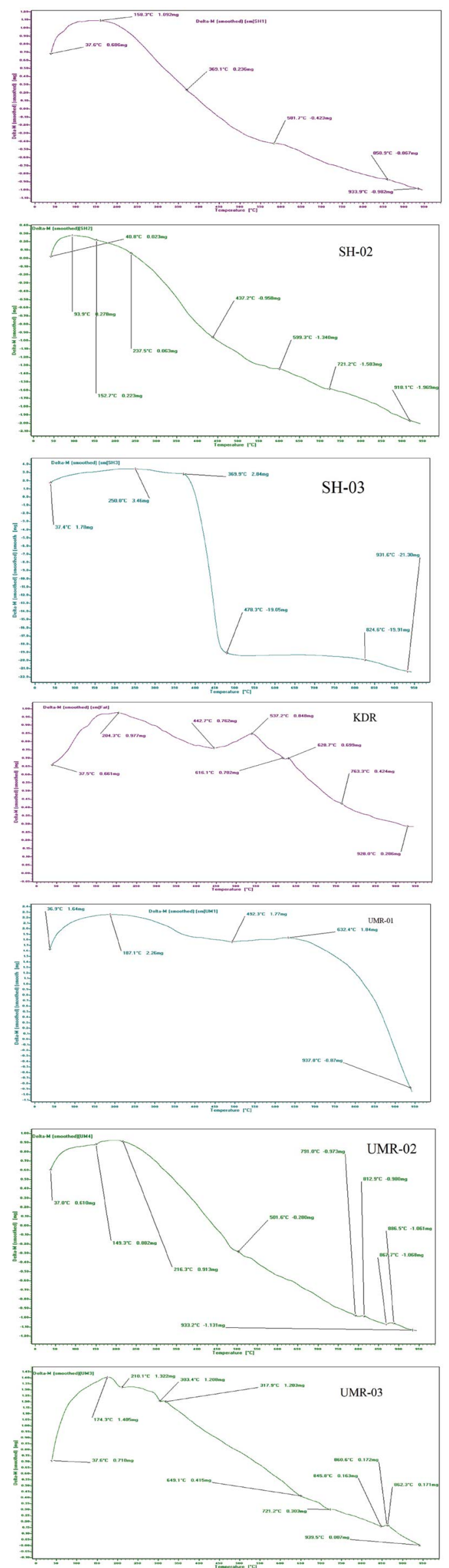

Figure 7: TGA diagram of the potsherds sample. served among room temperature and $300-400{ }^{\circ} \mathrm{C}$. Such thermal behavior is distinguishing of ceramics sintered in one time at a great temperature $[30,31]$.

\section{X-ray diffraction analysis}

Characterization of crystalline minerals was performed utilizing the $\mathrm{X}$-ray diffraction in the received state, and the data is shown in Table 5. the XRD pattern illustration great quantity of quartz and it is controlled and pointed out by the rich presence of this crystalline mineral by individual reflections of $(3.343,3.337,3.334$ and $3.335 \AA$ ) with all-out intensity. Moreover, feldspar compounds albite in UMR-02 sample assigned at (3.746, 3.479, 3.179, 2.940, 2.519, $2.234 \AA$ ) , microcline in the UMR-01, SH-03 $(6.477,3.822,3.699,3.593,3.482 \AA$ ) , Muscovite $(9.915,9.898,4.466,3.74 \AA ̊ \AA)$, illite $(9.898,3.286$ $\AA$ ) recognized as essential reflections in the majority of the samples. However, from mineralogical viewpoint the main features of the potsherds $\mathrm{SH}-01, \mathrm{SH}-$ 02 is rutile in their composition are quite similar and most possibly they were prepared from the same clay origin and firing situation; Moreover, containing rutile which phase of titanium oxide mostly changes into rutile which is a mineral enclosing $70 \%$ of titanium oxide between 800 and $1100^{\circ}$ [32]. The composition of the potsherd samples hold quartz, muscovite and microcline among the feldspars but do not hold calcite, the presence microcline suggests that shards were possibly fired at round $700{ }^{\circ} \mathrm{C}[22,33]$. However, the samples showed muscovite/illite in their composition, this shows are interrelated with FT-IR study for instance, the band $\left(727 \mathrm{~cm}^{-1}\right)$ in the UMR-01 and UMR-02 is related to the presence of muscovite in the potsherd samples [14,22], illite/ muscovite might show a firing temperature within range of $800-900{ }^{\circ} \mathrm{C}$ primarily due to the decomposition temperature of the illite structure [34]. The Figure 8 shows the XRD diffractogram of samples.

\section{Conclusion}

Mineralogical composition of the potsherds carried out by XRD analysis and FT-IR spectroscopy, that conclude the potsherd have various minerals composition, quartz, microcline, muscovite, illite, albite, rutile, manganese fluoride and magnesium aluminum silicon oxide, that revealed the potsherd have different source of production. XRF and SEMEDX characterization are estimated the sort of the clay, all sample are non-calcareous origin. Therefore, low refractory and no vitrification (NV) in (UMR-02 and SH-03) samples and initial vitrification 

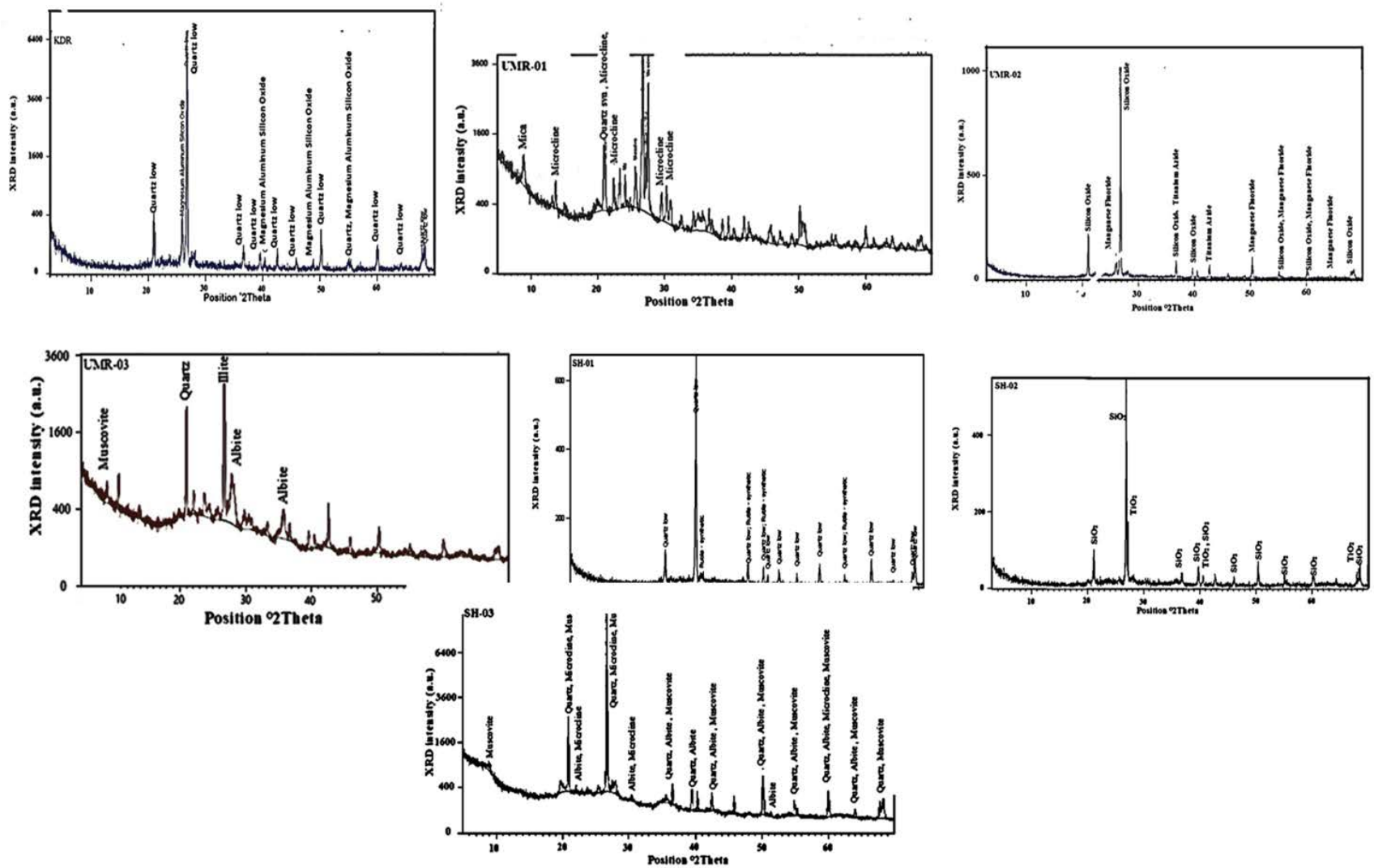

Figure 8: Diffractogram of XRD pattern of archaeological potsherds sample SH-01, SH-02, SH-03, UMR-01, UMR02, UMR-03 and KDR.

(IV) stage for the rest samples for all the fired clay. The constituents of heavy minerals are illustrated by the existence of iron, titanium, potassium, calcium, and other elements. Further, from the above investigation, can say that the artisans have fired the potsherd samples in temperature range of 800 $1100{ }^{\circ} \mathrm{C}$ in an oxidizing atmosphere with the slight interrelated consistency between the samples.

\section{Acknowledgments}

All the authors would like to thank the Arab-German Young Academy of Sciences and Humanities (AGYA) for research funding.

\section{References}

1. AM Pollard, CM Batt, B Stern, SMM Young (2007) Analytical chemistry in Archaeology.

2. G Artioli (2010) Scientific methods and cultural heritage. Oxford University Press, Oxford.

3. G Raja Annamalai, R Ravisankar, A Rajalakshmi, A Chandrasekaran, K Rajan (2014) Spectroscopic characterization of recently excavated archaeological potsherds from Tamilnadu, India with multi-analytical approach. Spectrochim Acta A Mol Biomol Spectrosc 113: 112-118.
4. F Kherbouche, J Dunne, S Merzoug, S Hachi, R Evershed (2016) Middle Holocene hunting and herding at Gueldaman Cave, Algeria: An integrated study of the vertebrate fauna and pottery lipid residues. Quaternary International 410: 50-60.

5. YM Elamin, AS Mohammed-Ali (2003) Umm Marrahi: An early holocene ceramic site, north Khartoum, Sudan. Adab 21: 1-82.

6. K Chłodnicki, M Kobusiewicz, M Kroeper (2011) The Lech Krzyżaniak Excavations in the Sudan, Kadero. Poznań Archaeological Museum.

7. LM Shillito, MJ Almond, K Wicks, LJR Marshall, W Matthews (2009) The use of FT-IR as a screening technique for organic residue analysis of archaeological samples. Spectrochimica Acta Part A: Molecular and Biomolecular Spectroscopy 72: 120-125.

8. S Shoval (2003) Using FT-IR spectroscopy for study of calcareous ancient ceramics. Optical Materials 24: 117-122.

9. VC Farmer, JD Russell (1964) The infra-red spectra of layer silicates. Spectrochim Acta 20: 1149-1173.

10. A Decarreau, O Grauby, S Petit (1992) The actual distribution of octahedral cations in 2:1 clay minerals: Results from clay synthesis. Applied Clay Science 7: 147-167.

11. WG Mumme, G Tsambourakis, IC Madsen, RJ Hill (1996) 
Improved petrological modal analyses from $\mathrm{x}$-ray powder diffraction data by use of the Rietveld Method. Part II. Selected sedimentary rocks. J Sediment Res 66: 132-138.

12.J Scrodon, VA Drits, DK McCarty, JCC Hsieh, DD Eberl (2001) Quantitative X-ray diffraction analysis of clay-baring rocks from random preparations. Clays and Clay Minerals 49: 514-528.

13.L Heller-Kallai (2001) Protonation-deprotonation of dioctahedral smectites. Applied Clay Science 20: 27-38.

14.D Seetha, G Velraj (2015) Spectroscopic and statistical approach of archaeological artifacts recently excavated from Tamilnadu, South India. Spectrochimica Acta Part A: Molecular and Biomolecular Spectroscopy 149: 58-68.

15.LF Vieira Ferreira, I Ferreira Machado, AM Ferraria, TM Casimiro, P Colomban (2013) Portuguese tinglazed earthenware from the $16^{\text {th }}$ century: A spectroscopic characterization of pigments, glazes and pastes. Applied Surface Science 285: 144-152.

16.Y Maniatis, MS Tite (1981) Technological examination of Neolithic - Bronze Age pottery from central and southeast Europe and from the Near East. Journal of Archaeological Science 8: 59-76.

17.L Maritan, L Nodari, C Mazzoli, A Milano, U Russo (2006) Influence of firing conditions on ceramic products: Experimental study on clay rich in organic matter. Applied Clay Science 31: 1-15.

18.M Hall, S Minyaev (2002) Chemical Analyses of Xiong-nu Pottery: A preliminary study of exchange and trade on the inner asian steppes. Journal of Archaeological Science 29: 135-144.

19.R Ravisankar, S Kiruba, C Shamira, A Naseerutheen, PD Balaji, et al. (2011) Spectroscopic techniques applied to the characterization of recently excavated ancient potteries from Thiruverkadu Tamilnadu, India. Microchemical Journal 99: 370-375.

20.L Damjanović, I Holclajtner-Antunović, UB Mioč, V Bikić, D Milovanović, et al. (2011) Archaeometric study of medieval pottery excavated at Stari (Old) Ras, Serbia. Journal of Archaeological Science 38: 818-828.

21.VC Farmer (1974) The Infrared Spectra of Minerals. London.

22.GE De Benedetto, R Laviano, L Sabbatini, PG Zambonin (2002) Infrared spectroscopy in the mineralogical characterization of ancient pottery. Journal of Cultural Heritage 3: 177-186.

23.MP Colombini, G Giachi, F Modugno, E Ribechini (2005) Characterisation of organic residues in pottery vessels of the Roman age from Antinoe (Egypt). Microchemical Journal 79: 83-90.

24.R Ravisankar, G Raja Annamalai, A Naseerutheen, A Chandrasekaran, MVR Prasad, et al. (2013) Analyti- cal characterization of recently excavated megalithic sarcophagi potsherds in Veeranam village, Tiruvannamalai dist., Tamilnadu, India. Spectrochim Acta A Mol Biomol Spectrosc 115: 845-853.

25.IC Freestone, AP Middleton (1987) Mineralogical applications of the analytical SEM in archaeology. Mineralogical Magazine 51: 21-31.

26.G Velraj, K Janaki, AM Musthafa, R Palanivel (2009) Estimation of firing temperature of some archaeological pottery shreds excavated recently in Tamilnadu, India. Spectrochimica Acta Part A: Molecular and Biomolecular Spectroscopy 72: 730-733.

27.C Papachristodoulou, A Oikonomou, $\mathrm{K}$ loannides, $\mathrm{K}$ Gravani (2006) A study of ancient pottery by means of X-ray fluorescence spectroscopy, multivariate statistics and mineralogical analysis. Analytica Chimica Acta 573-574: 347-353.

28.P Bruno, M Caselli, ML Curri, A Genga, R Striccoli, et al. (2000) Chemical characterisation of ancient pottery from south of Italy by Inductively Coupled Plasma Atomic Emission Spectroscopy (ICP-AES:) Statistical multivariate analysis of data. Analytica Chimica Acta 410: 193-202.

29.VA Drebushchak, LN Mylnikova, TN Drebushchak, VV Boldyrev (2005) The investigation of ancient pottery: Application of thermal analysis. Journal of Thermal Analysis and Calorimetry 82: 617-626.

30. P Colomban, DN Khoi, NQ Liem, C Roche, G Sagon (2004) Sa Huynh and Cham potteries: Microstructure and likely processing. Journal of Cultural Heritage 5: 149-155.

31.A Krapukaitytè, S Tautkus, A Kareiva, E Zalieckienè (2008) Thermal analysis - A powerful tool for the characterization of pottery. Chemija 19: 4-8.

32.NQ Liem, G Sagon, VX Quang, H Van Tan, P Colomban (2000) Raman study of the microstructure, composition and processing of ancient Vietnamese (proto) porcelains and celadons (13-16 ${ }^{\text {th }}$ centuries). Journal of Raman Spectroscopy 31: 933-942.

33.R Ravisankar, S Kiruba, A Chandrasekaran, A Naseerutheen, M Seran, et al. (2010) Determination of firing temperature of some ancient potteries of Tamil Nadu, India by FT-IR spectroscopic technique. Indian Journal of Science and Technology 3: 1016-1019.

34.M Bayazit, I Iskender, A Issi (2015) Vibrational Spectroscopy Investigating the fi ring technologies of Part-Roman potsherds excavated from Kuriki (Turkey) using thermal and vibrational spectroscopic techniques. Vibrational Spectroscopy 78: 1-11.

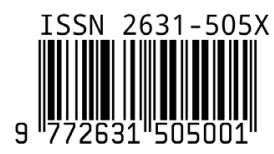

